\title{
ON SOME EEL EGGS AND LARVÆ FROM THE GULF OF MANAAR*
}

\author{
By R. Velappan NaIR AND B. S. Bhimachar \\ (From the Central Marine Fisheries Research Station, Calicut)
}

Received December 26, 1949

(Communicated by Dr. H. Srinivasa Rao, F.A.sc.)

\section{INTRODUCTION}

THOUGH much attention has been devoted to the elucidation of the biology of the eels, the records of their eggs are very few and, strangely enough, even the egg of the European eel, Anguilla vulgaris, which was the subject of intensive investigation, remains unknown to Science. The first account of eel eggs was by Raffaele (1888) who studied the early development of five types of unidentified eggs from the Bay of Naples. This was followed by Eigenmann's (1901) investigation on the development of an eel egg resembling Raffaele's "Species No. 6" collected 30 miles south of South Shoal and assigned by him to the Conger eel. Boeke (1903) described nine types of eel eggs and larvæ from the Naples Bay which included the types studied by Raffaele. Schmidt (1913) described the eggs of the Mediterranean Conger, Murana helena. He aiso collected the eggs of Nettastoma melanurum from the Balearic and Tyrrhenian Seas and identified Raffaele's "Species No. 7" and Boeke's "Muræna No. 3" as that of Ophichthys hispanus and Boeke's "Muræna No. 2" as that of Ophichthys serpens. Fish (1927) gave an account of the egg and larvæ of the American cel, Anguilla rostrata, collected 10 miles south-west of Bermuda Island. Recently Delsman (1933) described a few eggs and larvæ of eels obtained from the Java Sea.

The only record of eel eggs from Indian waters is by Aiyar, Unny and Varkey (1944, Abstract) from the Madras Coast.

The present study is based on a collection of twelve eel eggs and six larvæ obtained from the surface plankton collections made on the 12th (Lat. $8^{\circ} 44^{\prime} 54^{\prime \prime}$ N., Long. $78^{\circ} 19^{\prime} 5^{\prime \prime}$ E.) and the 13th (Lat. $8^{\circ} 44^{\prime} 54^{\prime \prime}$ N., Long. $78^{\circ} 20^{\prime} 15^{\prime \prime}$ E.) April, 1949 at Tholayiram Paar, one of the pearl banks in the Gulf of Manaar situated 11 miles off Tuticorin Bay with a depth of

\footnotetext{
* Published with the permission of the Chief Research Officer, Central Marine Fisheries Research Station, Mandapam Camp.
} 
8 to 11 fathoms. The sea bottom of this Paar consists of rocky outcrops supporting varied types of corals, sponges, sea weeds and other forms. The collections were made from 9-45 to 10 a.m. with a three-fourth meter organdie townet from M.F.V. "Gohar Khaleeli" at a speed of 2 knots. The hydrological conditions at the time of collection were:-

$\begin{array}{llcc} & & 12-4-1949 & 13-4-1949 \\ \text { Temperature } & \ldots & 29 \cdot 79^{\circ} \mathrm{C} & 29 \cdot 65^{\circ} \mathrm{C} . \\ \text { Specific Gravity } & \ldots & 1 \cdot 024 & 1 \cdot 024 \\ \text { Salinity } & \ldots & \text { not available } & 33 \cdot 87 \% \\ \text { pH } & \ldots & , & 8 \cdot 5\end{array}$

A detailed study of the eggs and larva could not be undertaken on board for want of facilities for such work and on account of rough weather at the time. The material was, therefore, fixed in $5 \%$ formalin and examined in the Laboratory later. The eggs had all the distinctive characters of eel eggs, viz., very large size, large perivitelline space and segmented yolk, and the characters of the egg and the developing embryo and the presence or absence of oil globule showed that they belonged to three distinct species of eels. The two types of eel larvæ present in the collection cannot definitely be said to belong to the eggs described here. In comparison with the larvæ described by Delsman they appear to be three or four days old.

\section{EGG I}

This eel egg seems to be common in the locality judging from the number (eight) present in the collection showing the embryo in different stages of development. The egg is transparent and spherical having a diamete I of $2.5 \mathrm{~mm}$. In the earliest stage obtained, only the indication of the formation of the embryo is seen as a streak (Fig. 1). The yolk is spherical with a diameter of $1.4 \mathrm{~mm}$. and shows the vacuolated or segmented nature very clearly. The perivitelline space is wide. Some eggs show the embryos in a fairly advanced condition with well formed eyes, otocyst, heart and œsophageal pouch (Fig. 2). The myotomes have differentiated of which 82 can be counted in this stage. The caudal end of the embryo is recurved and free from the yolk. The yolk mass is slightly elongated.

\section{EGG II}

This is the largest eel egg in the collection measuring $3.2 \mathrm{~mm}$. in diameter. It is perfectly transparent and spherical with a large perivitelline space. In the earliest stage obtained, the embryo is small and occupies about half the circumference of the yolk (Fig. 3). The yolk mass is spherical and clearly vacuolated. The eyes, otocyst, heart and œsophageal pouch 


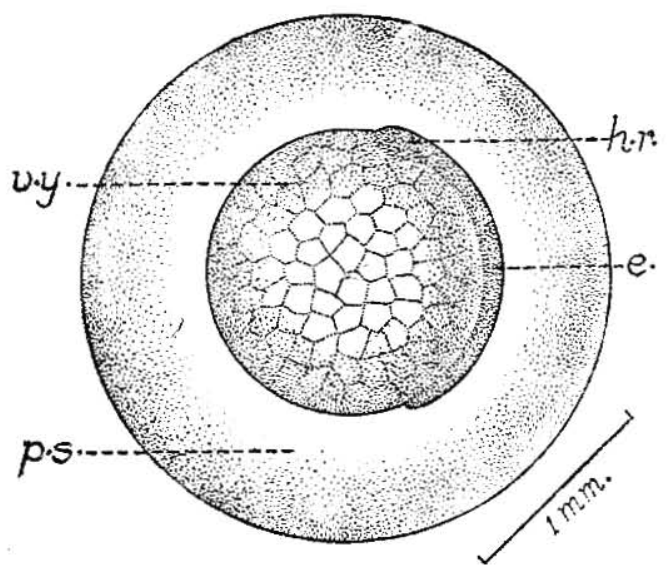

FIG. 1

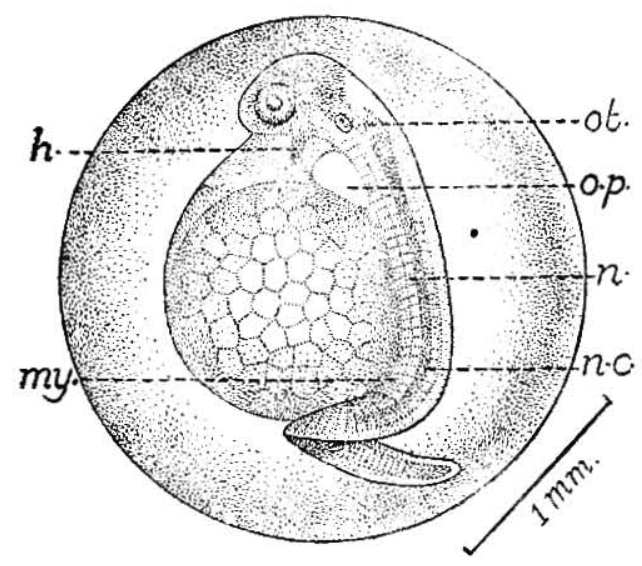

FIG. 2

Figs. 1 \& 2. Two stages in the development of Egg 1

have formed and 42 myotomes are seen faintly in this stage. In the next stage, the embryo is larger and completely encircles the elongate yolk mass with the caudal portion free from it (Fig. 4). About 105 myotomes are present in the embryo with the vent situated behind the yolk opposite the 73rd myotome. In a more advanced stage, the embryo is longer with the widened caudal portion showing distinct fin-folds (Fig. 5). More myotomes are formed in this stage and their number is 124 with the vent occupying the same position as in the previous stage. The yolk mass has

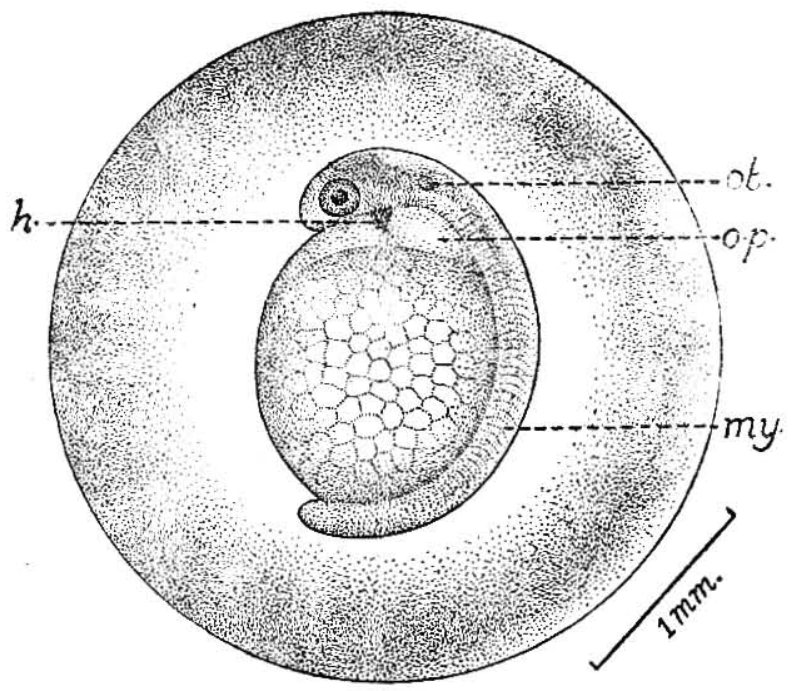

FIG. 3 


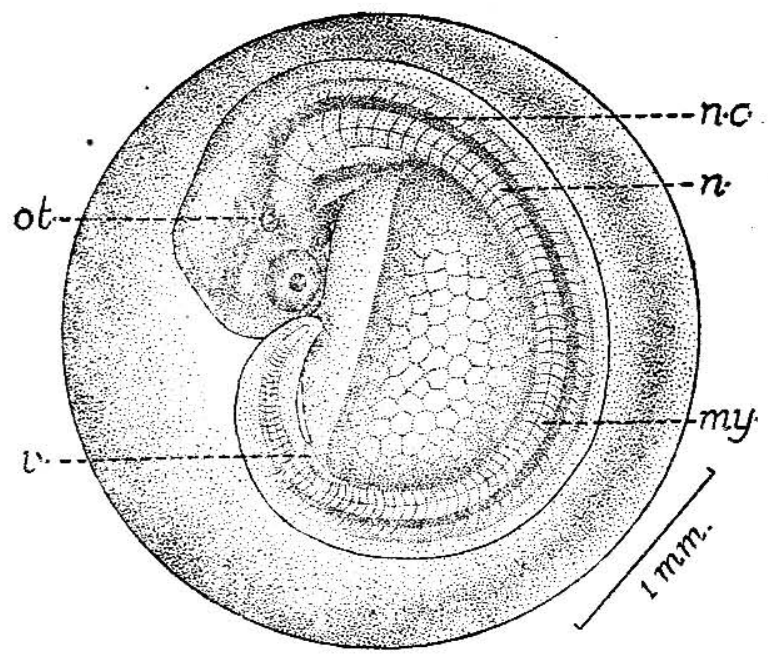

FIG. 4

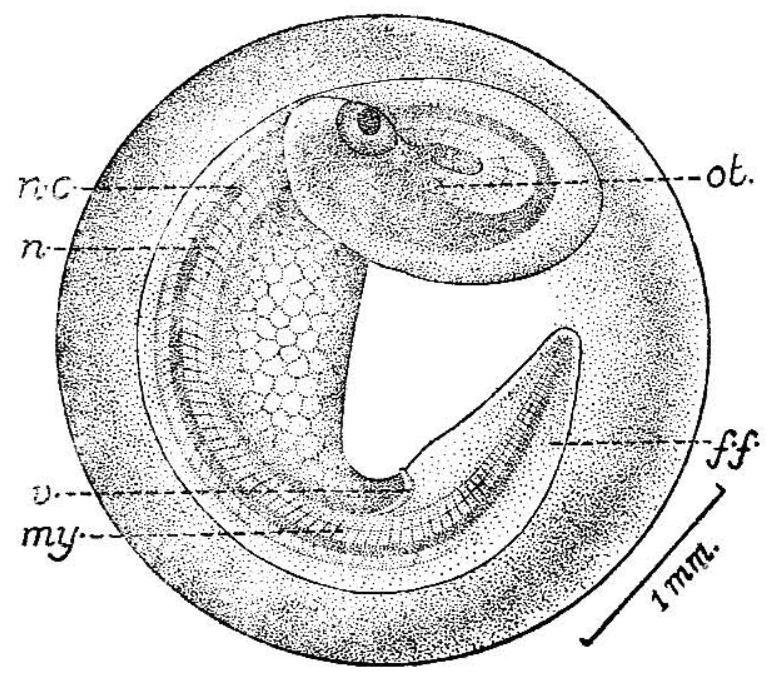

FIG. 5

Figs. 3 to 5. Three stages in the development of Egg II

- assumed an elongated fusiform shape and is confined to the posterior portion of the preanal region.

\section{EGG III}

There is a single egg of this type, $2.5 \mathrm{~mm}$. in diameter, in the collection. It is transparent and spherical (Fig. 6). The spherical vacuolated yolk is 
$1 \mathrm{~mm}$. in diameter. A single oblong oil globule is present peripherally in the yolk. The embryo is in an advanced stage of development with the long caudal portion free from the yolk. The eyes, otocyst, heart and œsophageal pouch have formed. 63 myotomes have already differentiated in this stage.

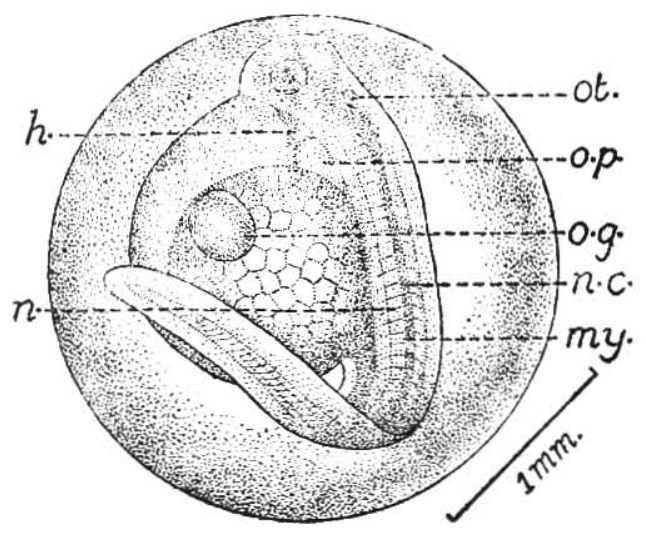

Fig. 6. Egg III

\section{LARVA I}

Three specimens of this larva are present in the collection. The larva is transparent and without chromatophores. It is $7.7 \mathrm{~mm}$. long from the snout to the caudal end with a maximum height of $1.2 \mathrm{~mm}$. including the fin-fold. The head is short and about $1 \mathrm{~mm}$. long (Fig. 7). The snout is very short and blunt (Fig. 8). The gape of the mouth extends to the anterior third of the eye. The lower jaw is slightly longer than the upper, and both the jaws are provided with four pairs of slender, tapering and anteriorly directed teeth which originate from the jaw cartilages (Fig. 9). The first pair of teeth in the upper jaw, $0.5 \mathrm{~mm}$. in length, is the best developed. The succeeding pairs are relatively short, but the last one is very small. The teeth of the lower jaw are more or less of the same size. The myotomes are well formed and distinct in the anterior region, while those of the posterior region, especially the postanal ones, are narrow, closely arranged and consequently not clearly distinguished. About 146 myotomes could be made out in the larva. The alimentary canal is very long and straight and the vent opens to the exterior at a level with the 84th myotome. The anterior third of the alimentary canal is narrow and this region is abruptly followed by the remaining wider region. No traces of yolk are seen in the larva. The larval fin is continuous from the nape to the anus. Rays have begun to form in the caudal region of the fin-fold. The pectoral fin is small, circular and without rays. 


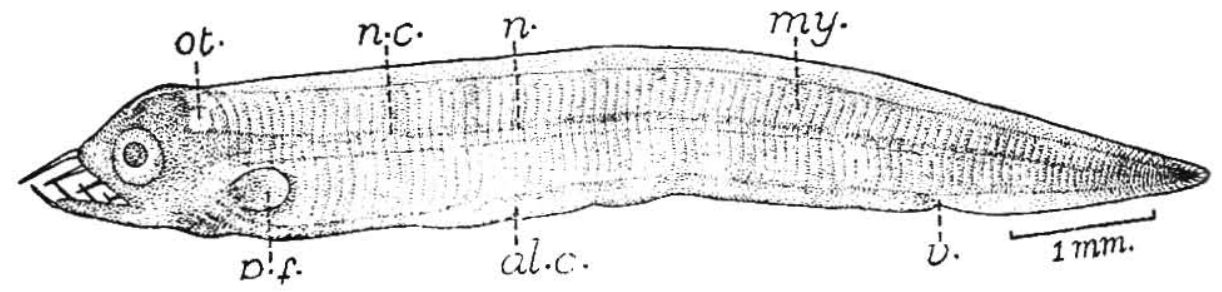

Fig. 7. Larva $\mathbf{I}$

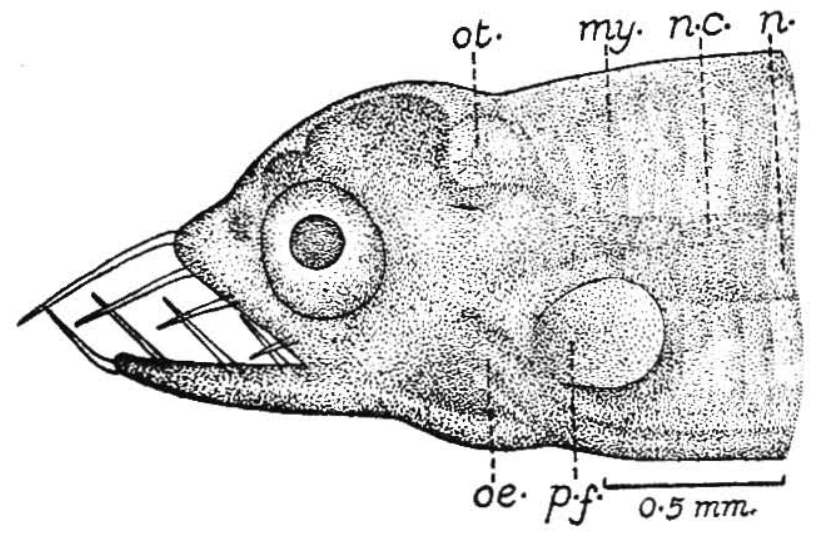

Fig. 8. Head region of Larva 1

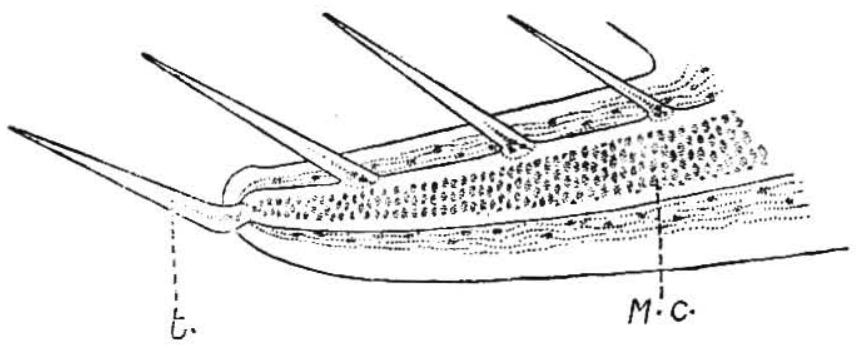

Fig. 9. Lower jaw of Larva I showing the origin of teeth from the Meckel's cartilage

\section{LARVA II}

There are three specimens of this larva in the collection which could be easily distinguished from Larva I by the characteristic shape of the head and pigmentation (Fig. 10). The larva is transparent and $7 \mathrm{~mm}$. in length from the snout to the caudal end and $1 \mathrm{~mm}$. in height including the fin-fold. The head, $1 \mathrm{~mm}$. long, is elongated with a long and sharply pointed snout (Fig. 11). The cleft of the mouth extends to the anterior border of the eye. The lower jaw is longer than the upper, and both carry four pairs of short, pointed and forwardly directed teeth. There are 78 myotomes clearly seen 


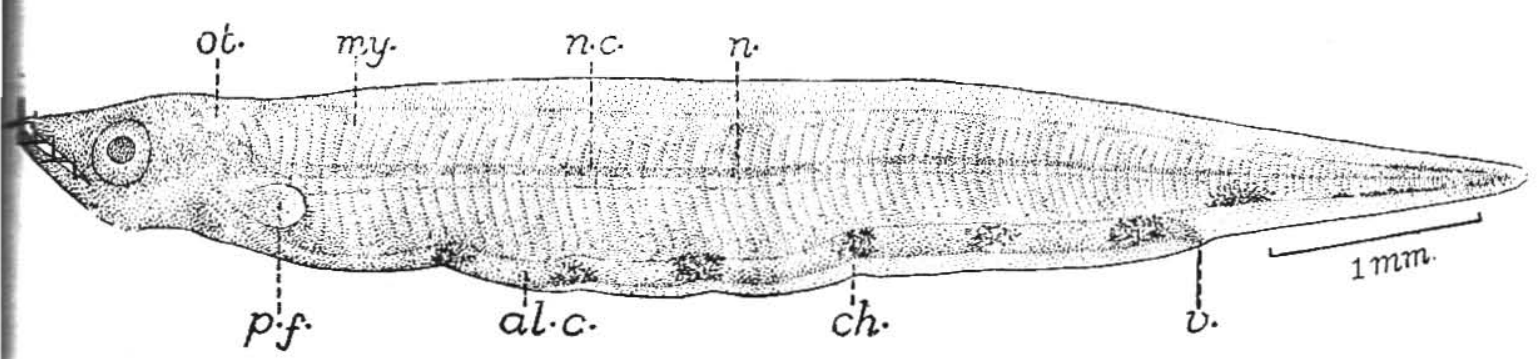

Fig. 10. Larva II

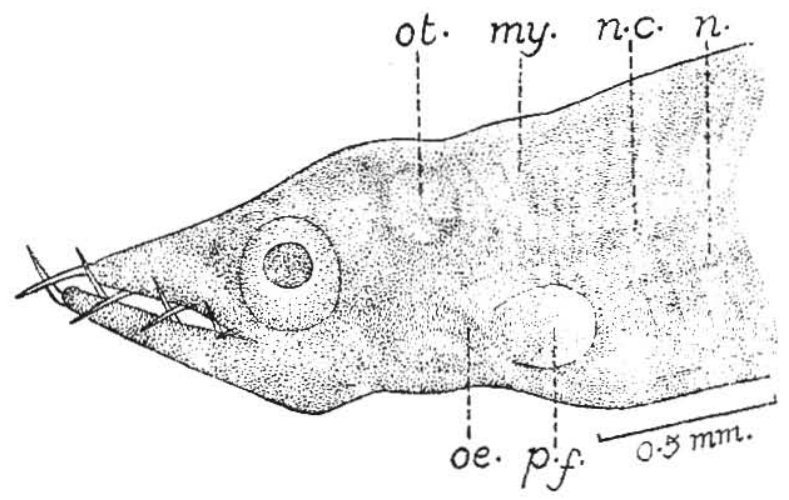

Fig. 11. Head region of Larva II

in the preanal region. The very compactly arranged postanal myotomes, numbering about 102 , could be made out with some difficulty. The continuous fin-fold commences from the nape and extends beyond the vent up to two-thirds on the ventral side showing formation of fin-rays in the caudal region. The pectoral fin is small, rounded and without rays. The long alimentary canal is incurved at intervals having a festoon-like appearance. Six prominent groups of black ramifying chromatophores are present along the alimentary canal at the incurvations. A linear group of similar dense pigment cells is present behind the anus. Such chromatophores are irregularly found along the bases of the dorsal and ventral fin-folds of the caudal region.

\section{REMARKS}

All the previous workers have experienced difficulty in determining the identity of the eel eggs studied by them and, with the exception of a few, the eggs have not been identified so far. This is also the case with regard to the many types of leptocephali recorded, the majority of which remains to be correlated with the adults. The identification of the eggs and larvæ described here is extremely difficult with our present meagre knowledge of the eels and leptocephali of the Indian waters. However, it may be men- 
tioned in this connection that Nair (1948) recorded the leptocephali of Congrellus anago, Uroconger lepturus, Murcenesox cinereus and Muræna sp. from the Gulf of Manaar.

The present study dealing with eggs in different stages of development including the very early stages would seem to indicate that Tholayiram Paar and neighbouring places afford favourable breeding grounds for Indian marine eels.

\section{ACKNOWLEDGEMENTS}

Our thanks are due to Dr. H. Srinivasa Rao for valuable suggestions and to Mr. K. Chidambaram for affording collection facilities in the Gulf of Manaar near Tuticorin and for furnishing the hydrological data.

\section{REFERENCES}

Aiyar, R. G., Unny, M. M. "Studies on Leptocephali of Madras Coast," Proc. 31st Ind. and Varkey, P. M.

*Boeke, J. Sci. Cong. (Abstract), 1944, 85.

.. Beitrage zur Entwicklungsgeschichte der Teleostier. 1. Petrus Camper, 2' Deel, 2' Aflevering, 1903.

Delsman, H. C.

.. "Fish Eggs and Larvæ from the Java Sea. 21. Eel Eggs," Treubia, 1933, 14, 237-47.

Eigenmann, C. H.

Fish, M. P.

Nair, R. V.

.. "The Egg and Development of the Conger Eel," Bull. U.S. Fish Comm., 1901, 21, 37-44.

. "Contributions to the embryology of the American eel (Anguilla rostrata Lesueur)," Zoologica, 1931, 8, 289-324.

Raffaele, F

"Leptocephali of the Gulf of Manaar," Proc. Ind. Acad. Sci., 1948, 27, 87-91.

Raffaele, F.

*Schmidt, J.

"Le uova galleggianti e la larve dei Teleostei nel golfo di Napoli," Mitt. Zool. Stat. Neapel, 1888, 8, 1-84.

. "On the identification of murænoid larvæ in their early (preleptocephaline) stages," Meddel. fra Komm. for Havun., 1913, Fiskeri Bind 4, Nr. 2, 1-14.

* References marked with an asterisk have not been referred to in the original.

KEY TO LETTERING

$\begin{array}{llll}\text { al.c. } & \text { alimentary canal } & \text { oe. } & \text { cesophagus } \\ \text { ch. } & \text { chromatophore } & \text { o.g. } & \text { oil globule } \\ \text { e. } & \text { embryo } & \text { o.p. } & \text { cesophageal pouch } \\ \text { f.f. } & \text { fin-fold } & \text { ot. } & \text { otocyst } \\ \text { h. } & \text { heart } & p . s . & \text { perivitelline space } \\ \text { h.r. } & \text { head region } & p . f . & \text { pectorai fin } \\ \text { M.c. } & \text { Meckel's cartilage } & t . & \text { tooth } \\ \text { my. } & \text { myotome } & v . & \text { vent } \\ n . & \text { notochord } & v . y . & \text { vacuolated yolk } \\ \text { n.c. } & \text { nerve cord } & & \end{array}$

